\title{
Effect of recombinant bovine somatotropin on leukocyte mRNA expression for genes related to cell energy metabolism, cytokine production, phagocytosis, oxidative burst, and adaptive immunity
}

\author{
P. R. B. Silva, ${ }^{*}$ C. D. Nelson, $†$ J. P. Driver, $\dagger$ W. W. Thatcher, $\dagger$ and R. C. Chebel ${ }^{\star} \dagger \ddagger \S^{1}$ \\ *Department of Animal Science, University of Minnesota, Saint Paul 55108 \\ †Department of Animal Sciences, and \\ ‡Department of Large Animal Clinical Sciences, University of Florida, Gainesville 32608 \\ $\S$ Department of Veterinary Population Medicine, University of Minnesota, Saint Paul 55108
}

\section{ABSTRACT}

Objectives of the current experiment were to evaluate the effects of treatment of periparturient dairy cows with recombinant bovine somatotropin (rbST) on mRNA expression in peripheral leukocytes for genes related to the somatotropic axis, cell energy metabolism, and innate and adaptive immune responses. Cows were enrolled in the experiment at $253 \pm 3 \mathrm{~d}$ of gestation and assigned to an untreated control group $(\mathrm{n}=98)$ or to receive $125 \mathrm{mg}$ of rbST weekly from -21 to 21 $\mathrm{d}$ relative to calving $(\mathrm{rbST} 125 ; \mathrm{n}=98)$. Data from a subsample of cows (control $=16$, rbST125 $=16$ ) are reported herein. Hemogram and polymorphonuclear leukocyte (PMNL) phagocytosis, oxidative burst, and expression of adhesion molecules were determined weekly, from $-28 \pm 3$ to $24 \pm 3$ d relative to calving. Cows were vaccinated with ovalbumin at $-21 \pm$ $3,-7 \pm 3$, and $7 \pm 3$ d relative to calving. Serum $\operatorname{IgG}$ anti-ovalbumin and haptoglobin optical densities were determined weekly, from $-28 \pm 3$ to $24 \pm 3$ d relative to calving. Leukocytes were isolated from whole blood on $\mathrm{d}-21 \pm 3,-7 \pm 3$, and $7 \pm 3$ relative to calving to determine leukocyte mRNA expression for 66 genes. Cows in the rbST125 treatment had greater concentration of granulocytes $1 \mathrm{wk}$ prepartum (control $=3.7 \pm 0.4$ vs. $\operatorname{rbST} 125=4.6 \pm 0.4 \times 10^{9}$ cells $\left./ \mathrm{L}\right)$. Expression of CD18 by PMNL during the prepartum $($ control $=3,262 \pm 280$ vs. $\operatorname{rbST} 125=3,926 \pm 260$ geometric mean fluorescence intensity) and percentage of PMNL positive for phagocytosis and oxidative burst 1 wk postpartum $($ control $=59.2 \pm 2.8$ vs. $\operatorname{rbST} 125=$ $67.6 \pm 3.1 \%$ ) were increased in rbST125 cows. Postpartum IgG anti-ovalbumin optical density was higher in rbST125 cows than control cows (control $=1.5 \pm 0.1$

Received October 4, 2016.

Accepted June 18, 2017.

${ }^{1}$ Corresponding author: rcchebel@ufl.edu vs. $\operatorname{rbST} 125=1.9 \pm 0.1$ optical density). On d -7 relative to calving, leukocyte mRNA expression of $I G F 1 R$ and $J A K 1$ tended to be downregulated and expression of DEFB3 tended to be upregulated by rbST treatment. Expression of mRNA for STAT1, RELA, and NOD2 tended to be upregulated, expression of $R A C 2$ was downregulated, and expression of $J A K 3, B L K$, and $T N F \alpha$ tended to be downregulated on $\mathrm{d} 7$ relative to calving by rbST treatment. Effects of treatment of periparturient cows with $125 \mathrm{mg}$ of rbST on leukocyte gene expression were minute; thus, additional experiments are necessary to elucidate how rbST-induced increases in growth hormone and insulin-like growth factor-1 concentrations may modulate the immune response of periparturient cows.

Key words: dairy cow, leukocyte gene expression, somatotropin

\section{INTRODUCTION}

Periparturient dairy cows are immunosuppressed due to the stress of parturition and initiation of lactation. Peripheral blood lymphocytes and neutrophils have reduced function from approximately 2 wk before until 2 to 3 wk after parturition (Kehrli et al., 1989a,b). The timeline of immunosuppression in periparturient cows coincides with decreased concentrations of IGF1 , a cell growth and differentiation factor involved in the regulation of innate and adaptive immune functions (Heemskerk et al., 1999). Leukocytes can produce IGF-1 and express IGF-1 receptors (Merimee et al., 1989). Insulin-like growth factor-1 has been shown to modulate a variety of immune cell functions in human and mice models, including immune cell proliferation (Merimee et al., 1989), chemotaxis (Tapson et al., 1988), T-cell activation (Johnson et al., 1992), inhibition of neutrophil apoptosis (Kooijman et al., 2002), PMNL phagocytosis and oxidative burst (Inoue et al., 1998), and B-cell differentiation, maturation, and proliferation (Gibson et al., 1993; Funk et al., 1994). 
Treatment of healthy lactating cows with recombinant (r)bST has been shown to induce an increase in PMNL and total leukocyte count in circulation and increased PMNL oxidative burst activity and NADPH-oxidase activity (Burvenich et al., 1999). Furthermore, addition of rbST or IGF-1 in cultured peripheral blood lymphocytes from lactating dairy cows enhanced lymphocyte proliferation (Chang et al., 1996). Although treatment of periparturient dairy cows with rbST increases serum IGF-1 concentrations during the peripartum period, despite the uncoupling of the somatotropic axis (Vicini et al., 1991; Gulay et al., 2004a,b), little is known about its effects on immune response. In recent experiments conducted by our group, treatment of periparturient Holstein cows with $125 \mathrm{mg}$ of rbST increased IGF-1 concentrations (Silva et al., 2015, 2017a,b) and resulted in increased PMNL expression of the adhesion molecule CD62L, phagocytosis and oxidative burst, and serum optical density of ovalbumin-specific IgG (Silva et al., 2015). In addition, cows treated with $125 \mathrm{mg}$ of rbST had reduced incidence of retained fetal membranes and metritis (Silva et al., 2015, 2017a) and reduced haptoglobin optical density at $7 \mathrm{~d}$ postpartum (Silva et al., 2015).

Enhanced knowledge of the processes that regulate and potentiate the capacity of immune cells to fight and eliminate infections may lead to significant improvements in peripartum cow management and health. Administration of rbST to enhance leukocyte function might be an important strategy to prevent immunosuppression and infectious diseases in periparturient cows (Silva et al., 2015, 2017a,b). Thus, there is reason to explore the potential for this endocrine pathway as a regulator of immunity and the mechanisms involved in its actions. Therefore, the hypotheses of the current experiment were that weekly administration of $\operatorname{rbST}$ to periparturient dairy cows would upregulate peripheral leukocyte mRNA expression for genes related to somatotropic axis (e.g., GHR, IGF1R, STAT, JAK, and SOCS2), cell energy metabolism (e.g., INSR, LDHA, $P C 1, G S K 3 B, A C O X 1$, and PPAR), pathogen pattern recognition receptors (e.g., CD14, TLR, and NOD2), antimicrobial enzymes and peptides (e.g., $C A T H L$ and $D E F B$ ), phagocytosis and oxidative burst (e.g., $R A C 1$, $R A C 2$, $R H O A$, and $M P O$ ), cytokine production (e.g., $M Y D 88, N F K B 1, I L 1 B$, and TNFa), and antibody production (e.g., $B L K$ and $L Y N$ ). The objectives of the current experiment were to evaluate the effects of peripartum rbST treatment of dairy cows on peripheral leukocyte mRNA expression for genes related to the somatotropic axis, immune cells energy metabolism, and innate and adaptive immune responses.

\section{MATERIALS AND METHODS}

The procedures conducted during this experiment were approved by the Institutional Animal Care and Use Committee from the University of Minnesota (protocol 1408-31746A).

\section{Animals, Housing, and Nutrition}

Cows used in the current experiment are a subsample of the cows used by Silva et al. (2017a). Holstein cows (lactation $\geq 1$ ) from a commercial freestall dairy herd located in northwest Wisconsin were enrolled in the experiment at $253 \pm 3 \mathrm{~d}$ of gestation $(-28 \mathrm{~d}$ relative to calving). Cows were housed in the same naturally ventilated freestall barn from approximately $34 \mathrm{~d}$ prepartum to $21 \mathrm{~d}$ postpartum. As cows demonstrated signs of calving (discomfort, restlessness, tail twitching, and visualization of the allantoic sac through the vulva) they were moved from the freestall pen to a box stall. Within $12 \mathrm{~h}$ after calving, cows were moved to a postpartum freestall pen ( 1 to $21 \mathrm{~d}$ postpartum) for daily observation and examination for diagnosis of postpartum diseases. Composition of TMR fed during prepartum (far-off and close-up) and immediate postpartum (1 to $21 \mathrm{~d}$ postpartum) periods were described in Silva et al. (2017a). Cows were milked thrice daily. The DHIA measured milk yield weekly from $5 \pm 3$ to $21 \pm 3$ d postpartum from all cows, and milk data were recorded on DairyComp305 software (Valley Ag Software, Tulare, CA).

\section{Enrollment and Treatments}

At enrollment, cows were scored for body condition ( $1=$ emaciated and $5=$ obese; 0.25 -unit increments; Ferguson et al., 1994) and locomotion (1 = normal locomotion and $5=$ severely lame; as described by Sprecher et al., 1997). Healthy cows with BCS $\geq 2$ and locomotion score $\leq 2$ were balanced for lactation number, BCS, and previous lactation 305-d mature-equivalent milk yield and assigned randomly to 1 of 2 treatments: untreated control $(\mathrm{n}=98)$ or $125 \mathrm{mg}$ of rbST (Posilac, sometribove zinc suspension for injection; Elanco Animal Health, Greenfield, IN) weekly from -21 to $21 \mathrm{~d}$ relative to calving ( $\mathbf{r b S T 1 2 5} ; \mathrm{n}=98)$. In the course of the experiment, a subgroup of cows (16 per treatment) was selected based on predicted calving date and BCS for evaluation of leukocyte mRNA expression for genes of interest. Only data on innate and adaptive immune parameters and gene expression from these cows are reported herein. Data on health, milk yield, BCS, growth hormone (GH), IGF-1, and metabolite concentrations 
from all cows enrolled in the experiment may be found in Silva et al. (2017a).

Cows enrolled in the rbST125 treatment received 125 mg of rbST every $7 \mathrm{~d}$ from -21 to $21 \mathrm{~d}$ relative to calving. Injections of rbST were given subcutaneously in the neck area using 1-mL tuberculin syringes with 16 -gauge (5/8 in. long) hypodermic needles. Syringes containing $125 \mathrm{mg}$ of rbST were prepared 6 to $12 \mathrm{~h}$ before treatment. The contents of commercially available syringes of rbST were dispensed into sterile containers and the appropriate volume of $\mathrm{rbST}$ was aspirated into sterile syringes that were kept refrigerated. The syringes were warmed to room temperature $\left(15\right.$ to $\left.30^{\circ} \mathrm{C}\right)$ before rbST administration.

\section{Hemogram, PMNL Immune Response Assays, and Haptoglobin Assay}

Blood samples collected from the coccygeal vein or artery into 3-mL evacuated tubes containing $\mathrm{K}_{2}$ EDTA (Kendall Monoject, Mansfield, MA) were used for the hemogram. Samples were collected twice weekly from $-28 \pm 1$ to $24 \pm 1 \mathrm{~d}$ relative to calving. Blood samples were analyzed within $4 \mathrm{~h}$ of sample collection using a Vet Scan HM2 (Abaxis, Union City, CA) hemogram machine.

Blood samples collected twice weekly from $-28 \pm 1$ to $24 \pm 1 \mathrm{~d}$ relative to calving into $10-\mathrm{mL}$ heparinized evacuated tubes (Becton Dickinson Vacutainer Systems, Franklin Lakes, NJ) were used for determination of ex vivo innate immune responses by flow cytometry as described previously (Hulbert et al., 2011). Detailed information of the assays used to determine ex vivo innate immune responses were described in a previous experiment (Silva et al., 2015). Briefly, indirect immunofluorescence staining was used to determine PMNL expression of adhesion molecules L-selectin (also known as CD62L) and $\beta 2$ integrin (also known as CD18). Phagocytic and oxidative burst activities of peripheral PMNL were determined upon challenge with fluorescently labeled enteropathogenic bacteria (Escherichia coli 0118:H8) and oxidation of dihydrorhodamine 123 (Molecular Probes/Invitrogen, Eugene, OR). Flow cytometry was carried out on a BD FACScanto II (BD Biosciences, Franklin Lakes, NJ) and results were analyzed using FlowJo 7.6.4 software (Tree Star Inc., San Carlos, CA). The PMNL population was identified on basis of forward- and side-scattered properties. Data reported herein refer to percentages of PMNL positive for phagocytosis and oxidative burst and intensity of expression of CD18 and CD62L molecules and phagocytosis and oxidative burst as geometric mean fluorescence intensity (GMFI).
Haptoglobin optical density was determined by a colorimetric procedure (Hulbert et al., 2011). The intra- and interassay coefficients of variation were 4 and $3 \%$, respectively.

\section{Ovalbumin Immunization and IgG Anti-Ovalbumin Assay}

Cows were immunized with $0.5 \mathrm{mg}$ of chicken egg ovalbumin (Type VII; Sigma-Aldrich, St. Louis, MO) diluted in $0.5 \mathrm{~mL}$ of $\mathrm{PBS}$ and emulsified in Quil A adjuvant $(0.5 \mathrm{mg}$ of Quil A/0.5 mL of PBS; Accurate Chemical \& Scientific Corp., Westbury, NY) by subcutaneous injections in the neck area on $\mathrm{d}-21 \pm 3,-7 \pm$ 3 , and $7 \pm 3$ relative to calving. Blood sampled weekly from $\mathrm{d}-28 \pm 3$ to $24 \pm 3$ into 10-mL evacuated tubes without anticoagulant (Becton Dickinson Vacutainer Systems) was used to determine IgG anti-ovalbumin optical density. Blood tubes were placed on ice until centrifugation $\left(1,200 \times g\right.$ for 15 min at $\left.4^{\circ} \mathrm{C}\right)$ and serum was stored at $-32^{\circ} \mathrm{C}$ until analysis. Immunoglobulin $\mathrm{G}$ anti-ovalbumin optical density in serum was determined by ELISA and compared based on optical density (Mallard et al., 1997). A detailed assay procedure was described in a previous experiment (Silva et al., 2015).

\section{Leukocyte Isolation and mRNA Extraction and Quality Assessment}

Blood samples were collected at $-21 \pm 3,-7 \pm 3$, and $7 \pm 3 \mathrm{~d}$ relative to calving from the coccygeal vein or artery into 10-mL heparinized evacuated tubes (Becton Dickinson Vacutainer Systems) and placed on ice until leukocyte isolation and mRNA extraction to determine the expression of mRNA for 66 genes related to somatotropic axis, cell energy metabolism (Table 1), and immune responses (Table 2).

Peripheral blood leukocytes were isolated from 1 $\mathrm{mL}$ of whole blood and mRNA was extracted using the QIAamp RNA Blood mini columns kit procedure (Qiagen, Valencia, CA). Total RNA retained in the columns after extraction protocol was dissolved in $50 \mu \mathrm{L}$ of sterile RNase-/DNase-free water (Qiagen). Quantity and purity of the extracted RNA were measured using a NanoDrop spectrophotometer (ND-2000, NanoDrop Technologies Inc., Wilmington, DE) at 230, 260, and $280 \mathrm{~nm}$ absorbance waves. A portion of RNA sample solution, based on each sample's RNA yield, was diluted in RNase-/DNase-free water (Qiagen) to achieve a single concentration of $50 \mathrm{ng} / \mu \mathrm{L}$ across all samples. Diluted samples were reassessed using NanoDrop spectrophotometer to verify and readjust, if necessary, all samples to the final single concentration of $50 \mathrm{ng} / \mu \mathrm{L}$. 
Purity was accepted when the 280/260 and 260/230 absorbance ratios were $\geq 1.90$ and 1.80 , respectively.

For RNA integrity assessment, the Agilent 2100 Bioanalyzer (Agilent Technologies, Santa Clara, CA) was used. The RNA integrity number (RIN) was determined using the Agilent RNA 6000 Nano Kit (Agilent Technologies) according to the manufacturer's protocol. The acceptable values for high RNA integrity and low degradation range from 7 to 10; RIN values for all experimental samples were above 8 .

\section{Gene Expression Analysis, Selection of Reference Genes, and Data Normalization}

Leukocyte mRNA expression was assessed by direct digital quantification of hybridization of multiplexed target mRNA molecules with color-coded probe pairs, molecular barcodes, and single-molecule imaging using the NanoString nCounter System (NanoString Tech- nologies, Seattle, WA). The direct digital readout of each mRNA and its relative abundance was measured in $100 \mathrm{ng}$ of total RNA. The nSolver 2.0 Analysis Software (NanoString Technologies) was used to perform automated quality control to detect flags on imaging, binding density, linearity, and limit detection of control probes. Imaging and binding density quality controls were set to detect flags when the percentage of fields of view successfully counted by the digital analyzer scan was less than 75 and binding density was outside the 0.05 to 2.25 range. The positive control linearity and limit of detection quality control were set to flag lanes when positive control $\mathrm{R}^{2}$ values were less than 0.95 and when $0.5 \mathrm{f} M$ detection was $\leq 2$ standard deviations above the mean of the negative controls. No quality control flags were detected in the experimental samples.

The genes PPIE, SDHA, SPRYD4, UXT, XBP1, and $Y W H A Z$ (Table 1) were chosen as candidates for reference genes because they were stably expressed in

Table 1. Somatotropic axis- and cell energy metabolism-related genes and accession numbers according to National Center for Biotechnology Information (NCBI)

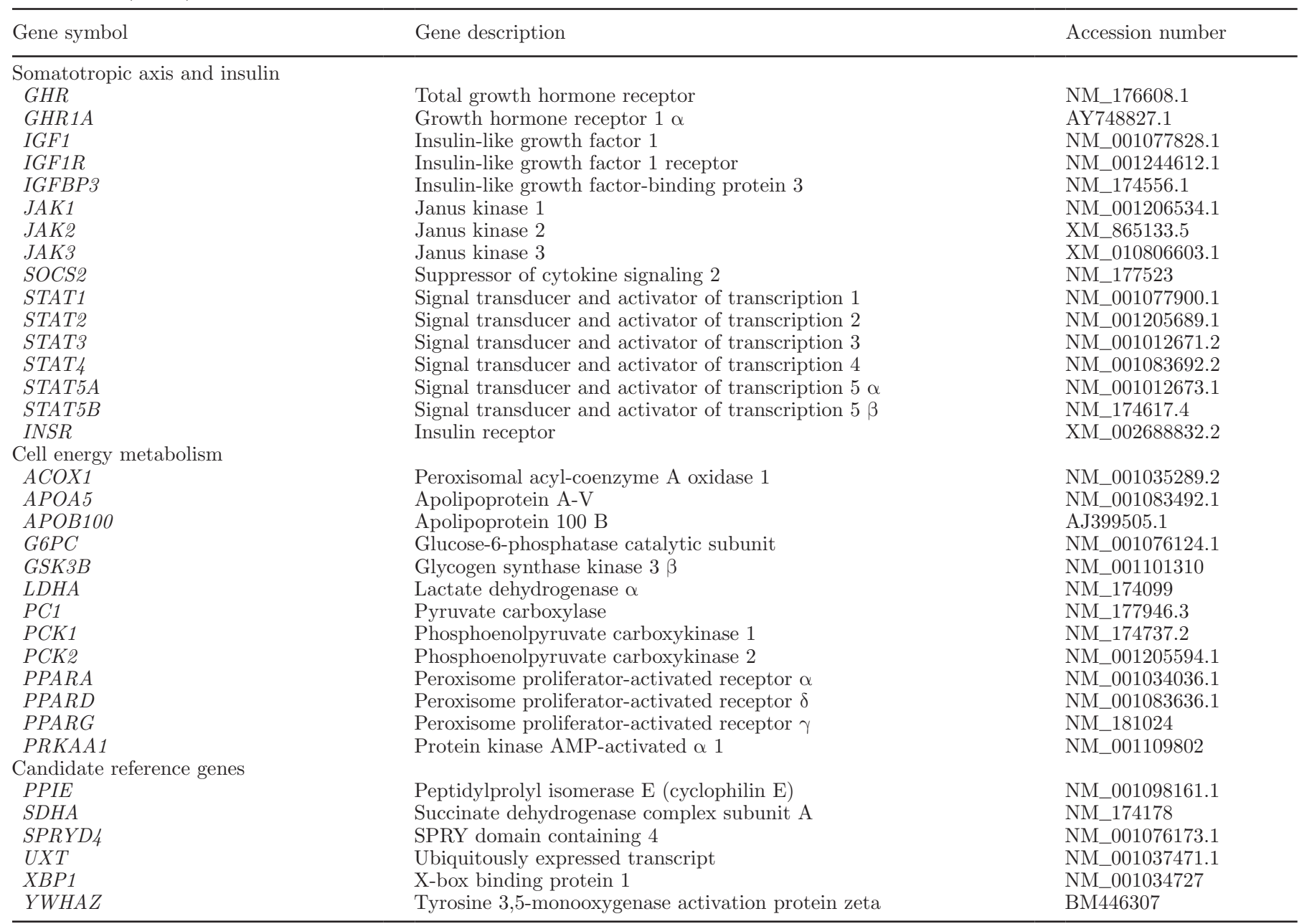


bovine lymphocytes (Spalenza et al., 2011), neutrophils (Stevens et al., 2011), and in liver tissue of periparturient Holstein cows treated with rbST (Silva et al., 2017b). Stability analysis to determine the most stable genes was performed using the NormFinder software (Andersen et al., 2004). Five genes (PPIE, SDHA, $U X T, X B P 1$, and $Y W H A Z$ ) were the most stable according to the NormFinder analysis and selected for use in the data normalization process.

To account for slight differences in hybridization and purification efficiency, data were normalized from each sample to its positive controls and selected reference genes using the nSolver 2.0 Analysis Software (NanoString Technologies). The positive hybridization controls are RNA control transcript sequences that are not homologous to any known organism and generate consistent results in gene expression analyses (NanoString Technologies), ranging from 10 to 10,000 counts. Positive controls allowed for the correction of sample-to-sample variation due to assay-specific factors such as differences in amount of input material or reagents. The negative correction was used to subtract the background noise from the positively corrected data using counts of 6 negative controls, sequence blank tags, by subtracting the negative controls' geometric mean +2 standard deviations. The normalization procedure consisted of adjustment of all mRNA count data to normalization factors generated specifically for each sample based on the geometric means, within and across all samples, of 6 positive controls and selected reference genes counts.

\section{Statistical Analysis}

All statistical analyses were conducted using SAS software (version 9.4; SAS Institute Inc., Cary, NC). In all models, cows were used as experimental unit. Dichotomous data (i.e., male calf) were analyzed by logistic regression using the LOGISTIC procedure. Continuous data were analyzed by ANOVA, and the assumption of normality of variables and residuals of continuous data were assessed using the residual output function. A log

Table 2. Immune function-related genes and accession numbers according to National Center for Biotechnology Information (NCBI)

\begin{tabular}{|c|c|c|}
\hline Gene symbol & Gene description & Accession number \\
\hline$B L K$ & B lymphocyte kinase & NM_001075968.2 \\
\hline$C 5 A R$ & Complement component 5 a receptor & NM 001007810.3 \\
\hline CATHL 5 & Cathelicidin 5 & NM_174510.3 \\
\hline CD14 & Cluster of differentiation 14 & NM_174008.1 \\
\hline CSF3 & Granulocyte-colony stimulating factor 3 & NM_174028.1 \\
\hline$D E F B Y$ & Defensin $\beta 7$ & NM_001102362.2 \\
\hline ERK1 & Extracellular signal-regulated kinase 1 & NM_001110018.1 \\
\hline ERK2 & Extracellular signal-regulated kinase 2 & NM_175793.2 \\
\hline IL1B & Interleukin $1 \beta$ & NM_174093.1 \\
\hline IL6 6 & Interleukin 6 & NM_173923.2 \\
\hline IL8 & Interleukin 8 & NM_173925 \\
\hline$L Y N$ & Tyrosine-protein kinase LYN & AB562971.1 \\
\hline NOD2 & Nucleotide-binding oligomerization domain-containing protein 2 & NM_001002889.1 \\
\hline NOX1 & NADPH oxidase 1 & NM_001191340.1 \\
\hline NOX2 & NADPH oxidase 2 & NM_174035.4 \\
\hline$P I K 3 C D$ & Phosphatidylinositol-4,5-bisphosphate 3-kinase, catalytic subunit delta & NM_001205548.1 \\
\hline$R A C 1$ & Ras-related C3 botulinum toxin substrate 1 & NM_174163.2 \\
\hline$R A C 2$ & Ras-related $\mathrm{C} 3$ botulinum toxin substrate 2 & NM_175792.2 \\
\hline$R E L A$ & v-rel avian reticuloendotheliosis viral oncogene homolog A & NM_001080242.2 \\
\hline RHOA & Ras homolog gene family, member A & NM_176645.3 \\
\hline$S C A R B 1$ & Scavenger receptor class B member 1 & NM_174597 \\
\hline SOD2 & Superoxide dismutase 2 & NM_201527.2 \\
\hline$S R C$ & Proto-oncogene tyrosine-protein kinase & NM_001110804.1 \\
\hline$S Y K$ & Spleen tyrosine kinase & NM_001037465.2 \\
\hline TLR2 & Toll-like receptor 2 & NM_174197.2 \\
\hline TLR4 & Toll-like receptor 4 & NM_174198.6 \\
\hline
\end{tabular}


natural transformation of dependent variables was applied to achieve a normal distribution when necessary. The MIXED procedure was performed to determine the differences between treatments regarding lactation number, 305-d mature-equivalent milk yield, and BCS at enrollment. The MIXED procedure was used to analyze continuous data with repeated measurements (hemogram, PMNL function, expression of adhesion molecules, IgG anti-ovalbumin, haptoglobin), including treatment, time, and the interaction between treatment and time as fixed effects. The structure of covariance (auto-regressive, unstructured, or compound symmetry) was chosen according to the Bayesian information criterion. The prepartum and postpartum periods were analyzed separately because of inherent physiological changes that occur during calving.

Effect of treatment on leukocyte mRNA expression at the different time points relative to calving was determined by ANOVA using the MIXED procedure. In all models, treatment was included as a fixed effect. In the model to determine the effect of treatment on leukocyte mRNA expression on $\mathrm{d}-7$ relative to calving, leukocyte mRNA expression on $\mathrm{d}-21$ relative to calving was included in the model as a covariate. Leukocyte mRNA expression on $\mathrm{d}-7$ relative to calving was not included in the model to evaluate the effect of treatment on leukocyte mRNA expression on $\mathrm{d} 7$ postpartum because of inherent physiological changes associated with calving. Before statistical analyses were conducted, dependent variables were evaluated for outliers and, within each variable, values greater than the mean plus 2 times the standard deviation were deleted. The percentage of data points removed from samples collected on $\mathrm{d}-21 \pm 3,-7 \pm 3$, and $7 \pm 3$ were 2.6 , 2.3 , and $6.5 \%$, respectively. There were no differences between treatments regarding the percentage of outlier data deleted within sampling day.

Statistical significance was defined as $P \leq 0.05$ and tendency was considered if $0.05<P \leq 0.10$. To control for family-wise error rate due to multiple-hypotheses testing when analyzing gene expression data, the Bonferroni method was applied, considering the 3 pathways being evaluated: somatotropic axis/insulin, cell metabolism (glucose/lipid), and immune function. Thus, statistical significance for gene expression was defined as $P \leq 0.017$ and tendency was considered if $0.017<$ $P \leq 0.033$.

\section{RESULTS}

\section{Descriptive Parameters at Enrollment and Calving}

At enrollment, average lactation number (control $=$ $1.9 \pm 0.2$ vs. $\operatorname{rbST} 125=1.7 \pm 0.2 ; P=0.35), \mathrm{BCS}$
$($ control $=3.5 \pm 0.1$ vs. $\operatorname{rbST} 125=3.5 \pm 0.1 ; P=0.55)$, previous lactation 305-d mature-equivalent milk yield (control $=12,037 \pm 675$ vs. $\operatorname{rbST} 125=12,409 \pm 675$ $\mathrm{kg} ; P=0.70$ ), and days of gestation (control $=252.9 \pm$ 0.3 vs. $r b S T 125=252.3 \pm 0.3 ; P=0.21)$ did not differ between treatments. Number of days that cows stayed in the prepartum pen during the trial tended $(P=$ 0.07 ) to differ between treatments (control $=26.4 \pm 0.8$ vs. $\operatorname{rbST} 125=24.3 \pm 0.8 \mathrm{~d}$ ). The percentage of cows calving male calves did not differ between treatments $($ control $=62.5$ vs. $\operatorname{rbST} 125=37.5 \% ; P=0.16)$.

\section{Effects of rbST Treatment on Hemogram Parameters, PMNL Phagocytosis and Oxidative Burst Activity, $P M N L$ Expression of CD62L and CD18, and Anti- Ovalbumin IgG and Haptoglobin Optical Densities}

Concentrations of total leukocytes during the prepartum $(P=0.26)$ and postpartum $(P=0.25)$ periods were not affected by treatment, but an interaction $(P=$ $0.03)$ between treatment and day was observed during the prepartum period as control cows tended (control $=12.0 \pm 1.2$ vs. $\operatorname{rbST} 125=8.9 \pm 1.2 \times 10^{9}$ cells $/ \mathrm{L} ; P$ $=0.08)$ to have higher leukocyte concentrations on $\mathrm{d}$ -21 than rbST125 cows (Table 3). No effect of treatment was observed on concentration of lymphocytes during the prepartum $(P=0.21)$ and postpartum $(P=$ $0.15)$ periods (Table 3 ). Concentration of granulocytes during the prepartum period was not $(P=0.93)$ affected by treatment (Table 3 ). The interaction between treatment and day relative to calving affected $(P=$ 0.01) granulocyte concentration prepartum; on $\mathrm{d}-7$ relative to calving, rbST125 cows tended $(P=0.09)$ to have greater granulocyte concentration than control cows $($ control $=3.7 \pm 0.4$ vs. $r b S T 125=4.6 \pm 0.4 \times$ $10^{9}$ cells $/ \mathrm{L}$ ). During the postpartum period, concentration of granulocytes $(P=0.92)$ was not affected by treatment (Table 3).

Percentage of PMNL positive for phagocytosis and oxidative burst were not affected by treatment during the prepartum $(P=0.18)$ and postpartum $(P=0.87)$ periods (Table 3 ). The interaction between treatment and day relative to calving tended $(P=0.10)$ to affect the percentage of PMNL positive for phagocytosis and oxidative burst during the postpartum period because rbS125 cows had $(P=0.05)$ a greater percentage of PMNL positive for phagocytosis and oxidative burst on d 0 postpartum than control cows (control $=59.2 \pm 2.8$ vs. $\operatorname{rbST} 125=67.6 \pm 3.1 \%$ ). During the prepartum and postpartum periods, the intensities of fluorescence for phagocytosis $(P=0.22$ and $P=0.81$, respectively) and oxidative burst $(P=0.22$ and $P=0.79$, respectively) were not affected by treatment (Table 3 ). Cows treated with rbST tended $(P=0.09)$ to have greater $\mathrm{CD} 18$ 
Table 3. Effect of treatment ${ }^{1}$ (Trt) on hemogram parameters, PMNL phagocytosis and oxidative burst, expression of adhesion molecules, and IgG anti-ovalbumin and haptoglobin optical densities (LSM \pm SEM)

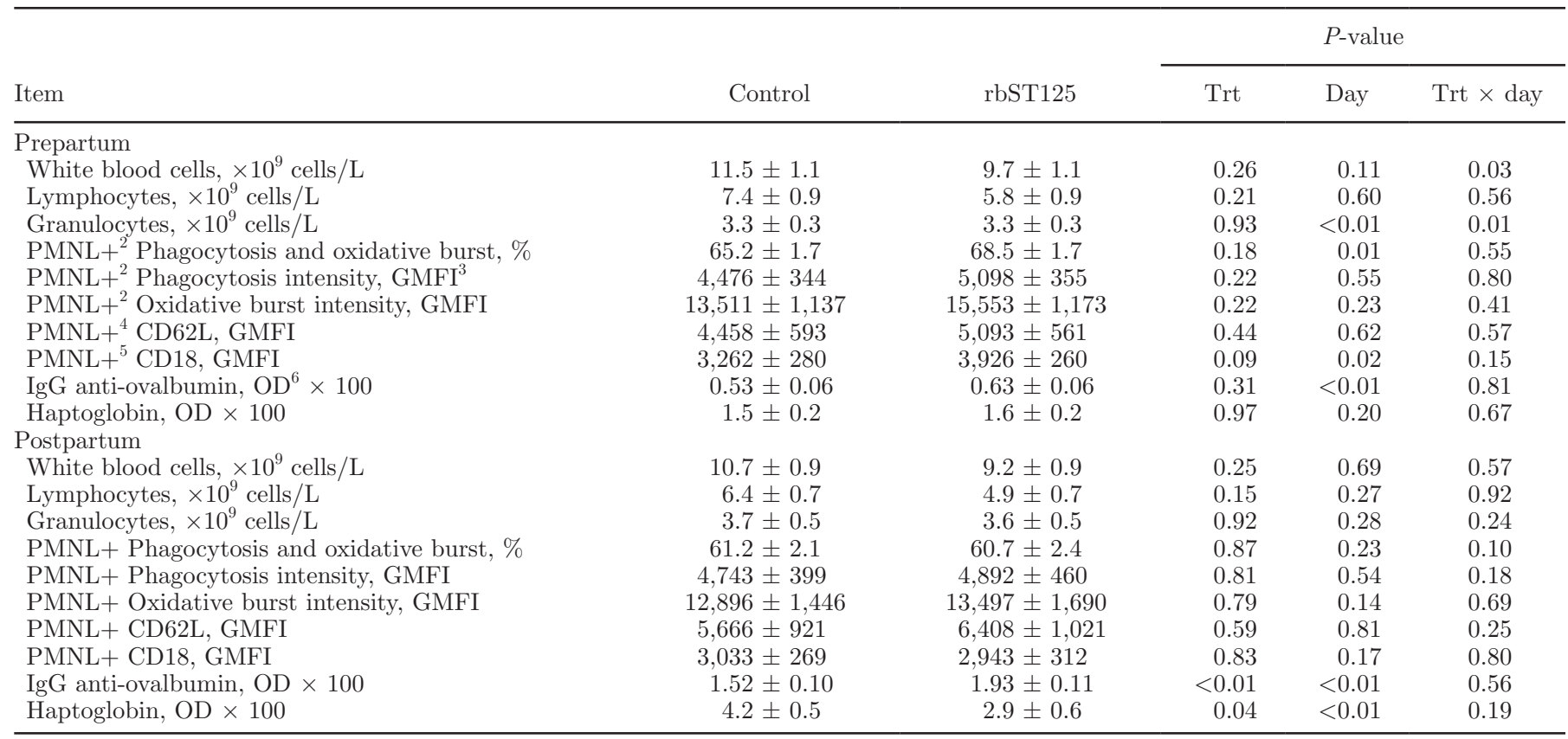

${ }^{1}$ Control $=$ cows received no treatment; rbST125 = cows received $125 \mathrm{mg}$ of recombinant (r)bST every $7 \mathrm{~d}$ from -21 to $21 \mathrm{~d}$ relative to calving.

${ }^{2}$ Polymorphonuclear leukocyte positive for phagocytosis and oxidative burst.

${ }^{3}$ Geometric mean fluorescence intensity.

${ }^{4}$ Polymorphonuclear leukocyte positive for CD62L.

${ }^{5}$ Polymorphonuclear leukocyte positive for CD18.

${ }^{6}$ Optical density.

expression by PMNL during the prepartum period than control cows, but no $(P=0.83)$ difference was observed during the postpartum period (Table 3). Expression of the adhesion molecule CD62L by PMNL during the prepartum $(P=0.44)$ and postpartum $(P=0.59)$ periods did not differ between treatments (Table 3 ).

Prepartum IgG anti-ovalbumin optical density did not $(P=0.31)$ differ between treatments, but rbST125 cows had $(P=0.01)$ greater IgG anti-ovalbumin optical density than control cows (Table 3) in the postpartum period.

Haptoglobin optical density was not affected by treatment during the prepartum period $(P=0.97)$, but control cows had $(P=0.04)$ higher haptoglobin optical density than rbST125 cows (Table 3) during the postpartum period

\section{Effects of rbST Treatment on Peripheral Leukocyte Gene Expression}

Nine genes (APOA5, APOB100, GCSF3, GHR1A, G6PC, IGF1, IGFBP3, IL6, and SRC) were not detected in leukocytes in the current experiment. At baseline (d -21), 6 genes (ACOX1, C5AR, IGF1R,
MYD88, $P C 1, S O D 2)$ were $(P \leq 0.017)$ and 4 genes (IL1B, STAT2, STAT3, TLR4) tended to be $(0.017<P$ $\leq 0.033)$ expressed differently between treatments. Of the 57 genes of interest detected in leukocytes, 10 were expressed differently between treatments on $\mathrm{d}-7, \mathrm{~d} 7$, or both relative to calving.

Genes Associated with the Somatotropic Axis. Expression of mRNA for IGF1R and JAK1 on $\mathrm{d}-7$ tended $(P \leq 0.030)$ to be reduced in rbST125 cows, but on $\mathrm{d} 7$ no differences $(P \geq 0.133)$ were detected between treatments in mRNA expression for IGF1R and JAK1 (Table 4). Although expression of mRNA for JAK3 was not $(P=0.051)$ affected by rbST treatment on $\mathrm{d}-7$, it tended $(P=0.019)$ to be downregulated on d 7 (Table 4). Expression of mRNA for STAT1 on d -7 was not $(P=0.661)$ affected by $\mathrm{rbST}$ treatment, but it tended $(P=0.032)$ to be upregulated on $\mathrm{d} 7$ postpartum by rbST treatment. Treatment had no $(P>0.10)$ effect on leukocyte mRNA expression for GHR, JAK2, SOCS2, STAT2, STAT3, STAT4, STAT5A, or STAT5B on d -7 and 7 relative to calving (Table 4 ).

Genes Associated with Cell Energy Metabolism. Treatment had no $(P>0.033)$ effect on leukocyte mRNA expression of genes involved in glucose 
SILVA ET AL.

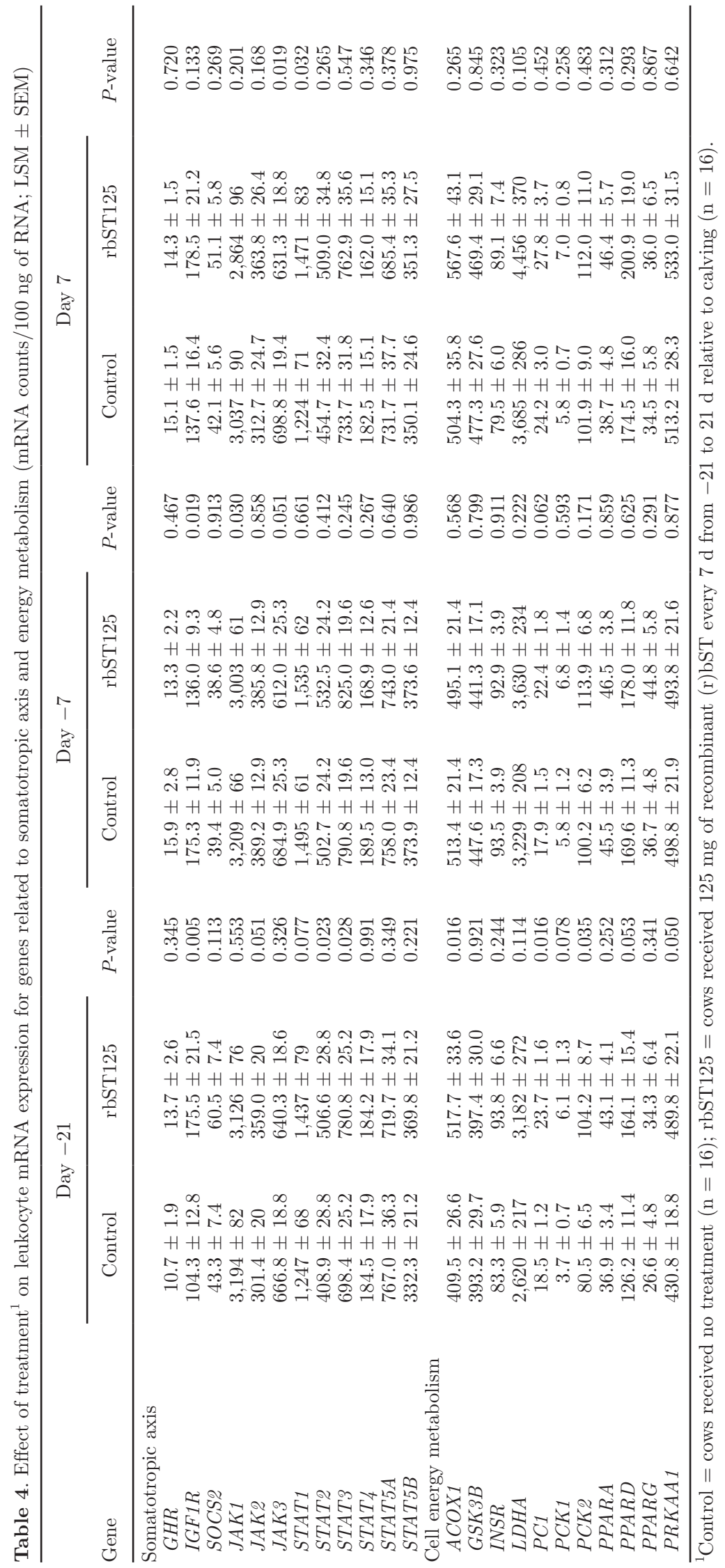


metabolism (INSR, GSK3B, PC1, PCK1, and PCK2) on $\mathrm{d}-7$ and 7 relative to calving. No effect of treatment $(P>0.033)$ was observed on mRNA for genes involved in lipid metabolism (ACOX1, LDHA, PPARa, PPARd, PPARg, and PRKAA1) on $\mathrm{d}-7$ and 7 relative to calving (Table 4).

Genes Associated with Complement and Innate Pathogen Receptors. Although treatment with rbST did not $(P=0.069)$ affect mRNA expression for NOD2 on d -7 , it tended to upregulate mRNA expression for NOD2 $(P=0.032)$ on $\mathrm{d} 7$ relative to calving (Table 5). Treatment did not $(P>0.033)$ affect the mRNA expression of C5AR, CD14, SCARB1, TLR2, or TLR4 on $\mathrm{d}-7$ and 7 relative to calving (Table 5 ).

Genes Associated with Antimicrobial Enzymes and Peptides. On $\mathrm{d}-7$, cows treated with rbST tended $(P=0.019)$ to have greater leukocyte mRNA expression for DEFB3 than control cows (Table 5). On d 7, no $(P>0.033)$ effects of treatment on mRNA expression for DEFB3 were observed (Table 5). Treatment had no $(P>0.033)$ effect on mRNA expression for CATHL4, CATHL5, DEFB4, DEFB7, MPO, NOX1, NOX2, or SOD2 on d -7 and 7 relative to calving (Table 5).

Genes Associated with Cytokines and Intracellular Signaling. Treatment with rbST125 did not $(P=0.582)$ affect mRNA expression for $T N F \alpha$ on $\mathrm{d}$ -7 , but it tended $(P=0.022)$ to downregulate the expression of mRNA for $T N F \alpha$ on d 7 relative to calving (Table 5). Leukocyte mRNA expression for $B L K$ on $\mathrm{d}-7$ was not $(P=0.088)$ affected by rbST treatment, but it tended $(P=0.022)$ to be downregulated in rbST125 cows on d 7 compared with control (Table $5)$. Similarly, the expression of mRNA for $R A C 2$ on $\mathrm{d}$ 7 was not $(P=0.095)$ affected by rbST treatment, but it was $(P=0.015)$ downregulated on $\mathrm{d} 7$ relative to calving in rbST125 cows compared with control cows (Table 5). Expression of mRNA for RELA on $\mathrm{d}-7$ was not $(P=0.867)$ affected by $\operatorname{rbST}$ treatment, but on $\mathrm{d} 7$ relative to calving, mRNA expression for $R E L A$ tended $(P=0.023)$ to be upregulated in rbST125 cows compared with control cows (Table 5). Treatment had no $(P>0.033)$ effect on mRNA for ATF3, ERK1, ERK2, IL1B, IL8, LYN, MAP3K 7, MYD88, NFAT, NFKB1, PIK $3 C D, R A C 1, R H O A, S Y K$, or TRAF6 on d -7 and 7 relative to calving (Table 5 ).

\section{DISCUSSION}

Leukocytes can produce GH and IGF-1 and express their receptors - GHR and IGF-1R (Rosenfeld et al., 1979; Merimee et al., 1989). Detection of IGF-1 and IGF-1R mRNA and the proteins they encode in peripheral blood leukocytes suggests that IGF-1/IGF-1R signaling pathways might exert regulatory functions on the immune system (Smith, 2010). Treatment of periparturient cows with $125 \mathrm{mg}$ of rbST increased prepartum serum IGF-1 concentrations compared with control cows (Silva et al., 2015, 2017a,b). In the current experiment, leukocyte mRNA expression for $G H R$ was not affected by rbST125 treatment and the genes GHR1A and IGF1 were not detected, suggesting that exogenous GH was not able to induce IGF-1 synthesis by leukocytes. In hepatic tissue, however, mRNA expression of $G H R, G H R 1 A$, and IGF1 were upregulated in periparturient cows treated with $125 \mathrm{mg}$ (Silva et al., 2017b). In the current experiment, leukocyte mRNA expression for $I G F 1 R$ tended to be upregulated on $\mathrm{d}-7$ in control cows, which had a more accentuated reduction on serum IGF-1 concentrations from d -24 to -3 relative to calving (data not shown). Upregulation of leukocyte mRNA for $I G F 1 R$ expression on $\mathrm{d}-7$ in control cows may be a cell mechanism response to maintain IGF-1R internal signaling during a drastic decrease in systemic IGF-1 concentrations. Upon binding to its receptors, GH initiates activation of JAK-STAT signaling pathways (Zhu et al., 1998). Expression of mRNA for $J A K 1$ and $J A K 3$ on d -7 and 7 , respectively, tended to be downregulated in cows treated with rbST. The reason for the rbST-induced downregulation of mRNA expression for $J A K 1$ in leukocytes is unknown, but may indicate a cell response mechanism to excess stimuli by exogenous GH in rbST125 cows. Expression of mRNA for STAT1 on d 7, however, was upregulated by treatment of periparturient cows with rbST. Little is known about the activation of STAT1 on leukocytes of the bovine. Experiments in mice, however, have demonstrated that overexpression of STAT1 suppresses the TNF- $\alpha$ induced activation of nuclear factor (NF)- $\kappa \beta$ (Wang et al., 2000). It is interesting to note that in the current experiment, expression of mRNA for $T N F \alpha$ was downregulated by $\mathrm{rbST} 125$ treatment on $\mathrm{d} 7$ relative to calving. Modulation of gene expression on $\mathrm{d} 7$ postpartum, particularly that of genes involved in immune and inflammatory responses, may be affected by the occurrence of diseases such as mastitis and metritis. In the current experiment, 4 of 16 control cows were diagnosed with metritis, whereas 0 out of 16 rbST125 cows were metritic.

In the current experiment, rbST treatment did not affect leukocyte mRNA expression for genes related to gluconeogenesis (i.e., PC1, PCK1, PCK2), glycogen synthesis (i.e., $G S K 3 B$ ), or lipid oxidation (i.e., $A C O X 1, L D H A, P P A R$ genes). In contrast, hepatic mRNA expression for PCK1 and ACOX1 was upregulated by treatment of periparturient cows with rbST (Silva et al., 2017b). During inflammation, extracellular glucose and intracellular glycogen stores are the preferred metabolic sources of energy used for activation, 


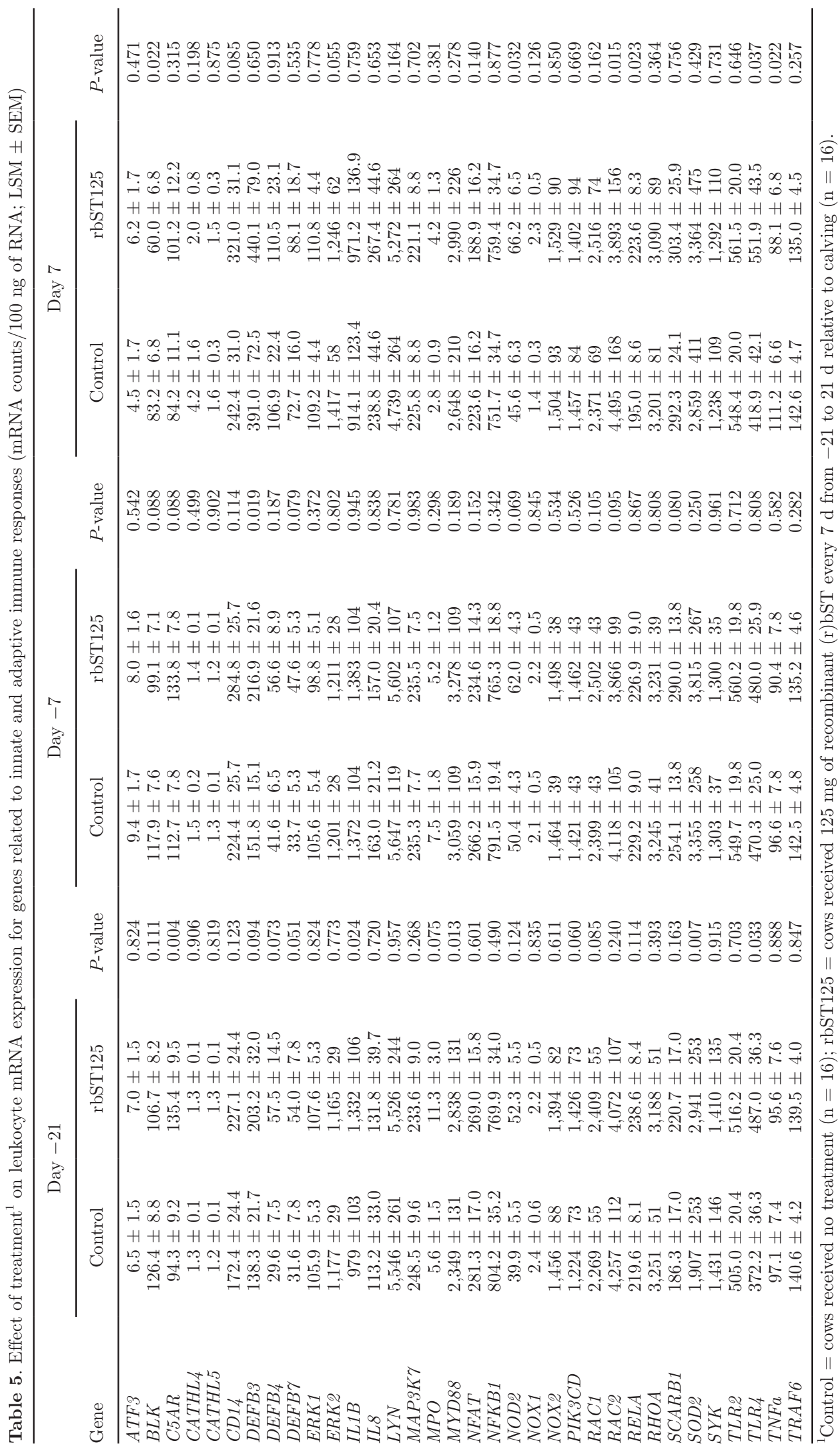


proliferation, survival, differentiation, phagocytosis, and chemotaxis of leukocytes (Weisdorf et al., 1982; Pithon-Curi et al., 2004). It is possible that the lack of differences between treatments regarding leukocyte expression of mRNA for genes involved in gluconeogenesis and lipid metabolism is a consequence of the lack of differences between treatments regarding plasma glucose, nonesterified fatty acid, and BHB concentrations in the current experiment (data not shown).

Leukocyte mRNA expression for the pathogen-associated molecular patterns (PAMP) receptor NOD2 tended to be upregulated on d 7 postpartum in rbSTtreated cows. Innate immune responses are initiated by cell surface receptors that detect PAMP and trigger internal signaling pathways that lead to the production of cytokines and chemokines, upregulation of adhesion molecules, and phagocytosis (Schiff et al., 1997; Tak and Firestein, 2001). Pathogen binding to PAMP recognition receptors induces receptor dimerization and recruitment of $M Y D 88$ that initiates the recruitment of TRAF6, which then activates the IKK $\alpha$ complex, allowing the translocation of NF- $\kappa \mathrm{B}$ to the nucleus for transcription of proinflammatory genes (Akira and Hoshino, 2003). In the current experiment, however, expression of mRNA for MYD88 and TRAF6 were not affected by treatment. It is important to note that on $\mathrm{d}-21$, we detected a numerical difference in expression of mRNA for NOD2 between control and rbST125 cows. Alterations in leukocyte mRNA expression on $\mathrm{d}$ 7 may be confounded by the occurrence of infectious diseases of the mammary gland and uterus, which may upregulate mRNA expression for NOD2 because of increased pathogenic load (Wang et al., 2015). Treatment of periparturient cows with $125 \mathrm{mg}$ of $\mathrm{rbST}$ reduces the incidence of retained fetal membranes and metritis (Silva et al., 2015, 2017a). Therefore, it is reasonable to suggest that rbST treatment in fact upregulated NOD2 mRNA expression, an important step in pathogen recognition and initiation of immune response.

Expression of mRNA for RAC2 was upregulated in control cows on $\mathrm{d} 7$ relative to calving. The gene $R A C 2$ encodes a protein member of the Rho-family GTPases that plays a key role in actin reorganization of cytoskeleton to promote membrane ruffling during the phagocytosis process induced by binding of microbes to specific cell surface receptors (Hall, 1994; Machesky and Hall, 1996). In addition, RAC2 is a key activator of the superoxide-generating NADPH oxidase in phagocytes, which plays an important role in oxidative burst microbial killing (Ridley, 1995). On d 0 relative to calving, rbST125 cows had greater percentage of PMNL positive for phagocytosis and oxidative burst, but this difference was not observed on $\mathrm{d} 7$ relative to calving. A larger number of cows in the control treatment were diagnosed with metritis in the current experiment (control $=4$ vs. rbST125 =0). This leads to the speculation that the uterine microbiota of control cows was more pathogenic early postpartum, which could have upregulated the expression of mRNA for RAC2. Boyer et al. (2011) demonstrated that cytotoxic necrotizing factor 1, produced by uropathogenic E. coli, upregulated RAC2 expression in drosophila, and Abe et al. (2011) demonstrated that $R A C 2$ was upregulated in periodontitis-affected gingival tissue.

Cows treated with rbST had upregulated leukocyte mRNA expression for encoding gene $D E F B 3$ on $\mathrm{d}-7$ relative to calving. $\beta$-Defensins are antimicrobial peptides that contribute to innate host defense via direct bactericidal activity and to adaptive immunity through effector and regulatory functions (Selsted and Ouellette, 2005). The mechanism of action of $\beta$-defensins involves membrane permeabilization and chemotactic behavior for cells of the adaptive immune system (Selsted and Ouellette, 2005). It has also been demonstrated that $\beta$-defensin 3 can activate antigen-presenting cells via TLR2 in a NF- $\kappa \mathrm{B}$-dependent manner (Funderburg et al., 2007). Insulin-like growth factor 1 has the potential to regulate the expression of antimicrobial peptides (Sørensen et al., 2003). Human keratinocytes expressed human $\beta$-defensin 3 in response to IGF-1 (Sørensen et al., 2003). Thus, it is likely that the rbST125-induced increase in IGF-1 concentrations during the prepartum upregulated the mRNA expression for DEFB3.

Upregulation of leukocyte mRNA expression for $B L K$ on $\mathrm{d} 7$ relative to calving in control cows did not translate into increased IgG optical density. In fact, postpartum serum optical density of anti-ovalbumin IgG was significantly increased in rbST125 cows compared with control cows, in agreement with our previous findings (Silva et al., 2015). The B cells play diverse roles in immune function by further differentiating into immunoglobulin-secreting plasma cells. Although total lymphocyte concentration was not different between control and rbST125 cows, IGF-1 enhances immunoglobulin production in a process independent of B-cell proliferation (Baudler et al., 2005). Signaling components downstream from IGF-1R may condition B-cell function. Activation of $\mathrm{B}$ cells through B-cell receptor triggers the src family of protein tyrosine kinases (PTK) Blk, Fyn, and Lyn (Sefton and Taddie, 1994). Texido et al. (2000) demonstrated that homozygous mutant mice free of $B L K \mathrm{mRNA}$ and Blk protein maintained B-cell development, in vitro activation, and antibody production. Thus, neither B-cell development nor B-cell responses in vitro and in vivo were altered by the lack of Blk. This suggests that other src-family 
PTK can compensate for the lack of Blk. Furthermore, in mice with $B L K / F y n$ doubly deficient $\mathrm{B}$ cells, a key role of Lyn on src-family PTK-mediated B-cell functions has been observed (Texido et al., 2000).

\section{CONCLUSIONS}

The minute effects of rbST on mRNA expression of peripheral leukocytes observed in the current experiment contrast with the positive effects of rbST treatment of periparturient cows on PMNL function, humoral immunity (measured by IgG anti-ovalbumin), and incidence of health disorders described in other experiments. Messenger RNA originates from active genes and is used as a template for proteins that determine the phenotype of immune cells; thus, mRNA expression can be used to investigate intracellular events in leukocytes. It should be noted, however, that mRNA undergoes posttranscriptional modifications that may or may not result in translation to active proteins. Therefore, measuring mRNA alone may have limitations to describe leukocyte mechanisms of action. In vivo experiments that evaluate peripheral leukocyte function work with the uncertain assumption that circulating leukocytes were in a resting stage or not activated before the start of treatments, as leukocytes were not in a controlled environment as provided by in vitro experiments. Additional experiments are warranted to evaluate mRNA expression of isolated immune cell lineages such as monocyte-macrophages, neutrophils, and $\mathrm{B}$ and $\mathrm{T}$ lymphocytes to determine which cell lineage-specific mechanisms are being modulated by rbST. In addition, measurements of phosphorylation and activation of internal signaling molecules involved in innate (e.g., phagocytosis and oxidative burst capacities of macrophages and neutrophils) and adaptive (e.g., cytotoxicity capacity of $\mathrm{T}$ lymphocyte and antibody production capacity of B lymphocytes) immune responses associated with measurements of protein yields as a result of upregulated mRNA transcription and translation are warranted to confirm the mechanisms that truly have a biological impact on immune cell function in cows treated with $\mathrm{rbST}$.

\section{ACKNOWLEDGMENTS}

The authors thank the owners, managers, and staff of Emerald II Dairy (Emerald, WI). Partial funding provided by CAPES Foundation, Ministry of Education of Brazil (Brasília, Brazil) and the HATCH Program, College of Veterinary Population Medicine, University of Minnesota (St. Paul).

\section{REFERENCES}

Abe, D., T. Kubota, T. Morozumi, T. Shimizu, N. Nakasone, M. Itagaki, and H. Yoshie. 2011. Altered gene expression in leukocyte transendothelial migration and cell communication pathways in periodontitis-affected gingival tissues. J. Periodontal Res. 46:345353.

Akira, S., and K. Hoshino. 2003. Myeloid differentiation factor 88-dependent and independent pathways in toll-like receptor signaling. J. Infect. Dis. 187(Suppl. 2):S356-S363.

Andersen, C. L., J. L. Jensen, and T. F. Orntoft. 2004. Normalization of realtime quantitative reverse transcription-PCR data: A model-based variance estimation approach to identify genes suited for normalization, applied to bladder and colon cancer data sets. Cancer Res. 64:5245-5250.

Baudler, S., J. Baumgartl, B. Hampel, T. Buch, A. Waisman, C. M. Snapper, W. Krone, and J. C. Bruning. 2005. Insulin-like growth factor-1 controls type $2 \mathrm{~T}$ cell-independent B cell response. J. Immunol. 174:5516-5525.

Boyer, L., L. Magoc, S. Dejardin, M. Cappillino, N. Paquette, C. Hinault, G. M. Charriere, W. K. Ip, S. Fracchia, E. Hennessy, D. Erturk-Hasdemir, J. Reichhart, N. Silverman, A. Lacy-Hulbert, and L. M. Stuart. 2011. Pathogen-derived effectors trigger protective immunity via activation of the Rac2 enzyme and the IMD or Rip kinase signaling pathway. Immunity 35:536-549.

Burvenich, C., M. J. Paape, D. Hoeben, H. Dosogne, A. M. MassartLeen, and J. Blum. 1999. Modulation of the inflammatory reaction and neutrophil defense of the bovine lactating mammary gland by growth hormone. Domest. Anim. Endocrinol. 17:149-159.

Chang, X., B. A. Mallard, and D. N. Mowat. 1996. Effects of chromium on health status, blood neutrophil phagocytosis and in vitro lymphocyte blastogenesis of dairy cows. Vet. Immunol. Immunopathol. 52:37-52.

Ferguson, J. D., D. T. Galligan, and N. Thomsen. 1994. Principal descriptors of body condition score in HO cows. J. Dairy Sci. $77: 2695-2703$.

Funderburg, N., M. M. Lederman, Z. Feng, M. G. Drage, J. Jadlowsky, C. V. Harding, A. Weinberg, and S. F. Sieg. 2007. Human-defensin-3 activates professional antigen-presenting cells via Toll-like receptors 1 and 2. Proc. Natl. Acad. Sci. USA 104:18631-18635.

Funk, P. E., P. W. Kincade, and P. L. Witte. 1994. Native associations of early hematopoietic stem cells and stromal cells isolated in bone marrow cell aggregates. Blood 83:361-369.

Gibson, L. F., D. Piktel, and K. S. Landreth. 1993. Insulin-like growth factor-1 potentiates expansion of interleukin-7 dependent pro-B cells. Blood 82:3005-3011.

Gulay, M. S., A. N. Garcia, M. J. Hayen, C. J. Wilcox, and H. H. Head. 2004a. Responses of Holstein cows to different bovine somatotropin (bST) treatments during the transition period and early lactation. J. Anim. Sci. 17:784-793.

Gulay, M. S., M. J. Hayen, M. Liboni, T. I. Belloso, C. J. Wilcox, and H. H. Head. 2004b. Low doses of bovine somatotropin during the transition period and early lactation improves milk yield, efficiency of production, and other physiological responses of Holstein cows. J. Dairy Sci. 87:948-960.

Hall, A. 1994. Small GTP-binding proteins and the regulation of the actin cytoskeleton. Annu. Rev. Cell Biol. 10:31-54.

Heemskerk, V. H., M. A. R. C. Daemen, and W. A. Buurman. 1999 Insulin-like growth factor-1 (IGF-1) and growth hormone $(\mathrm{GH})$ in immunity and inflammation. Cytokine Growth Factor Rev. 10:5-14.

Hulbert, L. E., J. A. Carroll, N. C. Burdick, R. D. Randel, M. S. Brown, and M. A. Ballou. 2011. Innate immune responses of temperamental and calm cattle after transportation. Vet. Immunol. Immunopathol. 143:66-74.

Inoue, T., H. Saito, T. Matsuda, K. Fukatsu, I. Han, S. Furukawa, S. Ikeda, and T. Muto. 1998. Growth hormone and insulin-like growth factor I augment bactericidal capacity of human polymorphonuclear neutrophils. Shock 10:278-284. 
Johnson, E. W., L. A. Jones, and R. W. Kozak. 1992. Expression and function of insulin-like growth factor receptors on anti-CD3activated human T lymphocytes. J. Immunol. 148:63-71.

Kehrli, M. E. Jr., B. J. Nonnecke, and J. A. Roth. 1989a. Alterations in bovine neutrophil function during the periparturient period. Am. J. Vet. Res. 50:207-214.

Kehrli, M. E. Jr., B. J. Nonnecke, and J. A. Roth. 1989b. Alterations in bovine lymphocyte function during the periparturient period. Am. J. Vet. Res. 50:215-220.

Kooijman, R., A. Coppens, and E. Hooghe-Peters. 2002. IGF-I inhibits spontaneous apoptosis in human granulocytes. Endocrinology 143:1206-1212.

Machesky, L. M., and A. Hall. 1996. Rho: A connection between membrane receptor signalling and the cytoskeleton. Trends Cell Biol. 6:304-310.

Mallard, B. A., L. C. Wagter, M. J. Ireland, and J. C. M. Dekkers, 1997. Effects of growth hormone, insulin-like growth factor-I, and cortisol on periparturient antibody response profiles of dairy cattle. Vet. Immunol. Immunopathol. 60:61-76.

Merimee, T. J., M. B. Grant, C. M. Broder, and L. L. Cavalli-Sforza. 1989. Insulin-like growth factor secretion by human B-lymphocytes: A comparison of cells from normal and pygmy subjects. J. Clin. Endocrinol. Metab. 69:978-984.

Pithon-Curi, T. C., M. P. De Melo, and R. Curi. 2004. Glucose and glutamine utilization by rat lymphocytes, monocytes and neutrophils in culture: A comparative study. Cell Biochem. Funct. $22: 321-326$

Ridley, A. J. 1995. Rac and Bcr regulate phagocytic phoxes. Curr. Biol. 5:710-712.

Rosenfeld, R., A. V. Thorsson, and R. L. Hintz. 1979. Increased somatomedin receptor sites newborn circulating human mononuclear cells. J. Clin. Endocrinol. Metab. 48:456-461.

Schiff, D. E., L. Kline, K. Soldau, J. D. Lee, J. Pugin, P. S. Tobias, and R. J. Ulevitch. 1997. Phagocytosis of gram-negative bacteria by a unique CD14-dependent mechanism. J. Leukoc. Biol. 62:786-794.

Sefton, B. M., and J. A. Taddie. 1994. Role of tyrosine kinases in lymphocyte activation. Curr. Opin. Immunol. 6:372-379.

Selsted, M. E., and A. J. Ouellette. 2005. Mammalian defensins in the antimicrobial immune response. Nat. Immunol. 6:551-557.

Silva, P. R. B., K. S. Machado, D. N. Lobão Da Silva, G. N. Moraes, D. H. Keisler, and R. C. Chebel. 2015. Effects of recombinant bovine somatotropin during the periparturient period on innate and adaptive immune responses, systemic inflammation, and metabolism of dairy cows. J. Dairy Sci. 98:4449-4464.

Silva, P. R. B., H. F. Soares, W. D. Braz, G. D. Bombardelli, J. A. Clapper, D. H. Keisler, and R. C. Chebel. 2017a. Effects of treatment of periparturient dairy cows with recombinant bovine somatotropin on health and productive and reproductive parameters. J. Dairy Sci. 100:3126-3142. https://doi.org/10.3168/jds 2016-11737.

Silva, P. R. B., W. J. Weber, B. A. Crooker, and R. C. Chebel. 2017b. Hepatic mRNA expression for genes related to somatotropic axis, glucose and lipid metabolisms, and inflammatory responses of dairy cows treated with recombinant bovine somatotropin during the periparturient period. J. Dairy Sci. 100:3983-3999. https://doi .org/10.3168/jds.2016-12135.

Smith, T. J. 2010. Insulin-like growth factor-I regulation of immune function: A potential therapeutic target in autoimmune diseases? Pharmacol. Rev. 62:199-236.

Sørensen, O. E., J. B. Cowland, K. Theilgaard-Mönch, L. Liu, T. Ganz, and N. Borregaard. 2003. Wound healing and expression of antimicrobial peptides/polypeptides in human keratinocytes, a consequence of common growth factors. J. Immunol. 170:55835589.

Spalenza, V., F. Girolami, C. Bevilacqua, F. Riondato, R. Rasero, C. Nebbia, P. Sacchi, and P. Martin. 2011. Identification of internal control genes for quantitative expression analysis by real-time PCR in bovine peripheral lymphocytes. Vet. J. 189:278-283.

Sprecher, D. J., D. E. Hostetler, and J. B. Kaneene. 1997. A lameness scoring system that uses posture and gait to predict dairy cattle reproductive performance. Theriogenology 47:1179-1187.

Stevens, M. G., L. J. Peelman, B. De Spiegeleer, A. Pezeshki, G. R. Van De Walle, L. Duchateau, and C. Burvenich. 2011. Differential gene expression of the toll-like receptor- 4 cascade and neutrophil function in early- and mid-lactating dairy cows. J. Dairy Sci. 94:1277-1288.

Tak, P. P., and G. S. Firestein. 2001. NF-kappaB: A key role in inflammatory diseases. J. Clin. Invest. 107:7-11.

Tapson, V. F., M. Boni-Schnetzler, P. F. Pilch, D. M. Center, and J. S. Berman. 1988. Structural and functional characterization of the human $\mathrm{T}$ lymphocyte receptor for insulin-like growth factor I in vitro. J. Clin. Invest. 82:950-957.

Texido, G., I. Su, I. Mecklenbrauker, K. Saijo, S. N. Malek, S. Desiderio, K. Rajewsky, and A. Tarakhovsky. 2000. The B-cell-specific src-family kinase Blk is dispensable for B-cell development and activation. Mol. Cell. Biol. 20:1227-1233.

Vicini, J. L., F. C. Buonomo, J. J. Veenhuizen, M. A. Miller, D. R. Clemmons, and R. J. Collier. 1991. Nutrient balance and stage of lactation affect responses of insulin, insulin-like growth factors I and II, and insulin-like growth factor-binding protein 2 to somatotropin administration in dairy cows. J. Nutr. 121:1656-1664.

Wang, Y., T. R. Wu, S. Cai, T. Welte, and Y. E. Chin. 2000. Stat1 as a component of tumor necrosis factor alpha receptor 1-TRADD signaling complex to inhibit NF-kappaB activation. Mol. Cell. Biol. 20:4505-4512.

Wang, H., G. Yu, H. Yu, M. Gu, J. Zhang, X. Meng, Z. Liu, C. Qiu, and J. Li. 2015. Characterization of TLR2, NOD2, and related cytokines in mammary glands infected by Staphylococcus aureus in a rat model. Acta Vet. Scand. 57:25-30.

Weisdorf, D. J., P. R. Craddock, and H. S. Jacob. 1982. Glycogenolysis versus glucose transport in human granulocytes: Differential activation in phagocytosis and chemotaxis. Blood 60:888-893.

Zhu, T., E. L. K. Goh, and P. E. Lobie. 1998. Growth hormone stimulates the tyrosine phosphorylation and association of P125 focal adhesion kinase (Fak) with Jak2 -Fak is not required for Statmediated transcription. J. Biol. Chem. 273:10682-10689. 